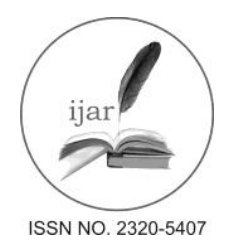

Journal homepage:http://www.journalijar.com

Journal DOI:10.21474/IJAR01

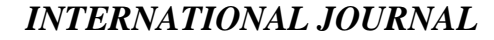

OF ADVANCED RESEARCH

RESEARCH ARTICLE

\title{
IMPACT OF MOLE DRAINS AND N-FERTILIZER RATES ON SOME SOIL PROPERTIES AND SUGAR BEET PRODUCTION IN CLAY SOIL.
}

\author{
El-Henawy A. S. ${ }^{1}$, Atta, M. Hamad ${ }^{2}$ and A. S. Antar ${ }^{3}$ \\ 1. Soil and Water Dept., Fac. of Agric., Kafrelsheikh University, Egypt \\ 2. Sugar Crops, Res. Inst., Agric. Res. Center, Egypt \\ 3. Soils, Water and Environment Res. Inst., Agric. Res. Center, Egypt
}

\section{Manuscript Info}

\section{Manuscript History:}

Received: 28 April 2016

Final Accepted: 11 May 2016

Published Online: June 2016

Key words:

*Corresponding Author

El-Henawy A. S.

\section{Abstract}

A field experiment was conducted during two winter seasons 2013/2014 and 2014/2015 at El-HamulDistrict, Kafr El-Shiek Governorate, Egypt, to study and evaluate the effect of mole drains ( 2 and $4 \mathrm{~m}$ spacing between the ploughed lines and $60 \mathrm{~cm}$ depth) and applied N-fertilizer rates $(100 \mathrm{~N}, 115 \mathrm{~N}$ and $130 \mathrm{~N} \%$ from the recommended) + 3 ton/fed. of gypsum before cultivation on improving some soil physio-chemical properties and sugar beet production in heavy clay salt affected soil.

Data showed that: Application of mole drainsseem to be more effective in decreasing soil salinity and sodcity especially, in the top soil $(0-60 \mathrm{~cm})$ and narrow spacing between the ploughed lines $(2 \mathrm{~m})$. The reduction of soil salinity $(0-60 \mathrm{~cm})$ were $21.11,21.44,17.04,11.74,11.17$ and $10.95 \%$ after the first season and 31.26, 31.37, 34.54, 12.34, 17.44 and $20.05 \%$ after the second season for treatment of $2 \mathrm{~m}$ spacing $+100 \% \mathrm{~N}, 2 \mathrm{~m}$ spacing $+115 \%$ $\mathrm{N}, 2 \mathrm{~m}$ spacing $+130 \% \mathrm{~N}, 4 \mathrm{~m}+100 \% \mathrm{~N}, 4 \mathrm{~m}$ spacing $+115 \% \mathrm{~N}, 4 \mathrm{~m}$ spacing $+130 \% \mathrm{~N}$, respectively than control. The corresponding values of ESP were $13.56,13.90,13.22,4.56,12.25$ and $11.85 \%$ after the first season and 18.81, $18.75,19.38,10.57,15.74$ and $16.93 \%$ after the second season respectively.Mole drains and gypsum seemed to be more effective on increasing $\mathrm{Ca}^{++} / \mathrm{TSS}$ ratio in the topsoil up to $60 \mathrm{~cm}$.

Mole drainsapplication was reduced bulk density and penetration resistance of the soil.Narrow spacing is superior to wider spacing in reducing bulk density and penetration resistance of the soil.Basic infiltration rates before treatments application was $0.61 \mathrm{~cm} / \mathrm{hr}$ while, after application varied from 1.56 to 1.85 $\mathrm{cm} / \mathrm{hr}$. Narrow spacing is superior to wider spacing in increasing basic infiltration rate. While, no obvious different between bulk density, penetration resistanceand basic infiltration values under $\mathrm{N}$-fertilizerrates treatments.

All moles drains treatments caused to significant increase in root and sugar yields in both seasons compared to control treatments. Root yield significant increased than control by $5.65,6.98,7.38,5.02,6.71$ and 7.37 ton/fed. In the first season and $4.87,6.53,6.67,4.70,6.14$ and 6.73 ton/fed. in the second season. In the same time sugar yield increased than control by $0.94,1.15,1.17,0.82,1.09$ and $1.16 \mathrm{ton} / \mathrm{fed}$. In the first season while at the second season the increase were 0.80 , $1.07,1.09,0.87$ and 1.01 ton/fed. On the other side quality \% recorded the highest value with control (81.48 and $81.22 \%$ ) in both seasons compared to other mole drains applications which recorded the lowest ones. 
The lowest values of $\mathrm{N}$-uptake ( 35.20 to $\left.36.44 \mathrm{~kg} . \mathrm{fed}^{-1}\right)$ were found with control, and the highest ones (44.10 to $55.38 \mathrm{kgfed}^{-1}$ ) were found with treatments in both seasons. The low values of impurities (K, Na andAlfa-amino $-\mathrm{N}$ ) in sugar beet roots were found with treatments compared to the control.

Copy Right, IJAR, 2016,. All rights reserved.

\section{Introduction:-}

Soil salinity and sodicity are one of the main agricultural problems limiting plant, growth and development in the world especially in arid and semiarid regions (Pessarakli, 2010). In Egypt, northern part of the Nile Delta represents a large area of heavy clay soils with shallow drainage which are low permeability that might have a low productivity.

Drainage plays a vital role in low permeable clay soils in order to prevent soil degradation. A secondary drainage treatment of moling seeks to be an inexpensive "drain" at close spacing, intercepted by permanent laterals at wider spacing. Moling is the best suited to clay soils with a minimum clay content of about $30 \%$. Mole drainage, on the suitable soil type and done properly can reduce waterlogging problems. Mole drainage is widely used on heavy soils to improve productivity of pastures and crops (David, 2002). Improved salt affected soils and crop growth following subsurface drainage and mole drains are generally considered to be the result of the physical shattering of the hardpan, which allows to increase water penetration into the subsoil. This may also accelerate the leaching of sodium from the subsoil thereby further reducing the possibility of reformation of the hardpan (Lickacz, 1993).Antar, et al., (2008 and 2014) and Aiad et al., 2012found that subsurface tillage seemed to be effective in lowering soil salinity and sodicity and bulk density especially in the soil depth $(0-60 \mathrm{~cm})$. Sugar beet yields are related to the salinity contents in soil.The yields increased when the EC decreased as affected by subsoiling and/or moling.

Alkali soils which are characterized by their adverse physical properties, their dispersed condition and impermeability to water, are to be directly connected with sodium as the dominant exchangeable base and the presence of magnesium silicate precipitated during the process of soil alkalinization. Gypsum applications followed by leaching, and biological methods such as growing salt-tolerant crops, were found successful in reclamation of a number of sodic and saline-sodic soils having good drainage conditions (Ahmad et al., 1990; Oster et al., 1996 and Reda 2006).

Sugar beet (Beta vulgaris L) is the second important crop for sugar production in Egypt. The importance of this crop comes not only for its ability for growing in the new reclaimed lands, but also for giving higher sugar content and short growth period. Also, sugar beet is widely grown in areas with salinity problems. So, there is a great need for several studies under Egyptian soil conditions to establish the best recommendations for raising the quantity and quality of sugar beet production. One way of increasing production of sugar beet is proper soil management such as drainage and increasing the efficiency of added nitrogen fertilizer. Sugar beetyield is affected by many factors such as drainage conditions and nitrogen fertilizer. Many investigators studied factors related to sugar beet yield among of them Aiad et al., (2012)and Antar et al., (2008 and 2014).Nitrogen is the most important nutrients required for all plants to obtain improving yield and its quality (Rees et al., 1995). Koranyand El-Said (1998) and El-Shahawy et al. (2001) concluded that improve root and top quality and sugar yield of sugar beet, may be due to improve soil structure and consequently the permeability and aeration.

The current study aims to study and evaluate the effect of mole drainsand applied $\mathrm{N}$-fertilizer rates on improving some soil physio-chemical properties and sugar beet production in heavy clay soil.

\section{Materials and methods:-}

A field experiment was conducted through two winter seasons 2013/2014 and 2014/2015 at El-HamulDistrict, Kafr El-Shiek Governorate, Egypt), to evaluate the effect of mole drains ( 2 and $4 \mathrm{~m}$ spacing between the ploughed lines and $60 \mathrm{~cm}$ depth) and applied $\mathrm{N}$-fertilizer rates $(100 \mathrm{~N}, 115 \mathrm{~N}$ and $130 \mathrm{~N} \%$ from the recommended dose) on 
improving some soil physio-chemical properties and sugar beet production in heavy clay salt affected soil. The location is situated at $31^{\circ} 18^{\prime} 12^{\prime \prime} 7 \mathrm{~N}$ latitude and $31^{\circ} 03^{\prime} 30^{\prime \prime} 5 \mathrm{E}$ longitude. Nitrogen fertilizer in the form of urea was added in three doses (before the first, second and the third irrigations). All plots received 3 ton/fed. of gypsum before cultivation as recommended. The different agricultural practices were done as recommended through the two growing seasons. The salinity of irrigation water ranges between $0.8-0.6 \mathrm{dSm}-1$ with an average of $0.70 \mathrm{dSm}^{-1}$. The initial of some soil properties for the experimental field are presented in Table (1).

The experiment design was a randomized complete block in seven treatments with three replicates as follows:

1. Open drainage $+100 \%$ of the recommended $\mathrm{N}(90 \mathrm{Kg} \mathrm{N} / \mathrm{fed})$ (control).

2. Mole drains at $2 \mathrm{~m}$ spacing $+100 \%$ of the recommended $\mathrm{N}(90 \mathrm{Kg} \mathrm{N} / \mathrm{fed})$.

3. Mole drains at $2 \mathrm{~m}$ spacing $+115 \%$ of the recommended $\mathrm{N}(104 \mathrm{Kg} \mathrm{N} / \mathrm{fed})$.

4. Mole drains at $2 \mathrm{~m}$ spacing $+130 \%$ of the recommended $\mathrm{N}(117 \mathrm{Kg} \mathrm{N} / \mathrm{fed})$.

5. Mole drains at $4 \mathrm{~m}$ spacing $+100 \%$ of the recommended $\mathrm{N}(90 \mathrm{Kg} \mathrm{N} / \mathrm{fed})$.

6. Mole drains at $4 \mathrm{~m}$ spacing $+115 \%$ of the recommended $\mathrm{N}(104 \mathrm{Kg} \mathrm{N} / \mathrm{fed})$.

7. Mole drains at $4 \mathrm{~m}$ spacing $+130 \%$ of the recommended $\mathrm{N}(117 \mathrm{Kg} \mathrm{N} / \mathrm{fed})$.

Before winter season 2013/2014, mole drains installation with twodistances between the ploughed lines (2and 4m) and $60 \mathrm{~cm}$ depth perpendicular to the open drainage. "Mole drains are unlined channels formed in a clay subsoil with a ripper blade with a cylindrical foot, often with an expander which helps compact the channel wall." Open drain was used to collect the drainage water brought by mole drain channels.

In the two growing seasons, seeds of sugar beet (pleno cultivar) were sown. The plants were thinned to one plant before the first irrigation. All plots received $100 \mathrm{KgCa}$-superphosphate/fed, and $50 \mathrm{Kg} \mathrm{K}$-sulfate/fed, during tillage operation. Soil samples $(0-15,15-30,30-60$ and 60-90cm depth) were collected before experiment and after the first and second seasons from treatments instillation for all treatments and monitored for some physical and chemical analysis. Salinity was determined in saturated soil best extract according to Page et al. (1982). Exchangeable sodium was determined using ammonium chloride and measured by using flame photometer according to Page et al. (1982). Soil bulk density and total porosity of the different layers of soil profile were measured before experiment and after the first and second seasons from treatments instillation for all treatments using the core sampling technique as described by Campbell (1994). Soil penetration resistance (SPR) was determined by hand penetrometer apparatus (Read by Newton/cm2) and, convert the Newton into Mega Pascal (MPa) values (100 Newton $/ \mathrm{cm}^{2}=1 \mathrm{Mega}$ Pascal). Infiltration rate was determined using double cylinder infiltrometer as described by Garcia (1978). At harvest, root and top yields and sugar yield as ton/fed were determined in both seasons.

Sucrose $\%$ and juice purity $\%$ were determined in Delta company sugar in El-Hamul district. Sugar yield was Calculated from multiplied root yield (ton / fed) $\mathrm{x}$ sucrose $\%$

Alkaline coefficient (Ac) calculated as follow:

$\mathrm{Ac}=[(\mathrm{Na}+\mathrm{K}) /(\alpha$-amino $\mathrm{N})]$ according to Wieninger and kubadinow 1971 and polloch 1984 .

Statistical analysis: Some of the obtained data are subjected to statistical analysis according to Snedecor and Cochran (1980). Treatments were compared by Duncan's multiple range test (Duncan, 1955)

Table 1:- The initial of some soil properties for the experimental field.

\begin{tabular}{|c|c|c|c|c|c|c|c|c|c|}
\hline \multirow{2}{*}{$\begin{array}{c}\text { Soil } \\
\text { depth } \\
(\mathrm{cm})\end{array}$} & \multicolumn{2}{|c|}{ Particle size distribution } & \multirow{2}{*}{$\begin{array}{c}\text { Texture } \\
\text { grade }\end{array}$} & $\begin{array}{c}\text { N } \\
(\mathrm{ppm})\end{array}$ & $\begin{array}{c}\text { EC } \\
(\mathrm{dS} / \mathrm{m})\end{array}$ & $\begin{array}{c}\text { ESP } \% \\
\begin{array}{c}\text { Bulk } \\
\text { density } \\
\text { g/cm }\end{array}\end{array}$ & $\begin{array}{c}\text { IR } \\
(\mathbf{c m} / \mathbf{h})\end{array}$ \\
\hline $\mathbf{0 - 1 5}$ & $\mathbf{1 3 . 2 9}$ & $\mathbf{3 0 . 2 8}$ & $\mathbf{5 6 . 4 3}$ & Clayey & $\mathbf{3 1}$ & $\mathbf{7 . 9 8}$ & $\mathbf{1 6 . 7 4}$ & $\mathbf{1 . 3 5}$ & $\mathbf{0 . 6 4}$ \\
\hline $\mathbf{1 5 - 3 0}$ & $\mathbf{1 3 . 7 1}$ & $\mathbf{3 0 . 6 5}$ & $\mathbf{5 5 . 6 4}$ & Clayey & $\mathbf{2 7}$ & $\mathbf{8 . 7 9}$ & $\mathbf{1 7 . 9 4}$ & $\mathbf{1 . 3 5}$ \\
\hline $\mathbf{3 0 - 6 0}$ & $\mathbf{1 4 . 8 8}$ & $\mathbf{2 9 . 8 4}$ & $\mathbf{5 5 . 2 8}$ & Clayey & $\mathbf{2 4}$ & $\mathbf{1 0 . 5 4}$ & $\mathbf{1 9 . 1 6}$ & $\mathbf{1 . 4 1}$ \\
\hline $\mathbf{6 0 - 9 0}$ & $\mathbf{1 4 . 8 7}$ & $\mathbf{3 1 . 2 4}$ & $\mathbf{5 3 . 8 9}$ & Clayey & $\mathbf{2 1}$ & $\mathbf{1 1 . 7 4}$ & $\mathbf{2 1 . 3 7}$ & $\mathbf{1 . 4 5}$ \\
\hline Mean & $\mathbf{1 4 . 1 9}$ & $\mathbf{3 0 . 5 0}$ & $\mathbf{5 5 . 3 1}$ & Clayey & $\mathbf{2 5 . 8}$ & $\mathbf{9 . 7 6}$ & $\mathbf{1 8 . 8 0}$ & $\mathbf{1 . 3 9}$ & \\
\hline
\end{tabular}




\section{Results and discussion:- \\ Soil salinity and sodcity:-}

Data presented in Tables (1 and 2) show that, application of mole drainsseem to be more effective in decreasing soil salinity and sodcity in presence gypsum. The salinity and sodcity of the soil increased markedly with the increasing of soil depth. Soil salinity and sodcityin the topsoil up to $60 \mathrm{~cm}$, before treatments application (Table, 1) are relatively high $\left(E_{\mathrm{e}}\right.$ varied from 7.98 to $10.54 \mathrm{dSm}^{-1}$ and ESP from 16.74 to 19.16) comparing with that after the first and second seasons (Table, 2) which, varied from 5.13 to $9.24 \mathrm{dSm}^{-1}$ for $\mathrm{EC}_{\mathrm{e}}$ and 13.05 to 17.56 for ESP. The decreases of soil salinity and sodcity in the topsoil up to $60 \mathrm{~cm}$, after the second season of treatment installation are more pronounced compared to that after one season (Table, 2). Salinity and sodcityof the soil are decreased in the upper layer $(0-60 \mathrm{~cm})$ in all treatments while, no decrease was shown in the deeper layer $60-90 \mathrm{~cm}$. These results might be explained by the effect of mole drains on water table recession, which occurred only through mole depth and thus contributed to an active salt transfer during the falling of water table. It could be concluded that in heavy textured soils, the ponding conditions under open drains, realizes desalinization of the surface soil layers and partly of the subsurface layers. Whereas, mole drains is effective in removing salts from the upper layers only. Salt leaching from deeper layers depends on the efficiency of drainage system.Similar results were obtained byMoukhtar et al., (2003) and Abdel-Mawgoud et al. (2003).

It is clear that narrow mole spacing $(2 \mathrm{~m})$ is superior to wider mole spacing $(4 \mathrm{~m})$ in reducing soil salinity and sodcityin both seasons. This may be due to the good effectiveness of narrow mole spacing $(2 \mathrm{~m})$ than wider mole spacing $(4 \mathrm{~m})$. The reduction of soil salinity in the topsoil up to $60 \mathrm{~cm}$, were $21.11,21.44,17.04,11.74,11.17$ and $10.95 \%$ after the first season and 31.26, 31.37, 34.54, 12.34, 17.44 and $20.05 \%$ after the second season for treatment of $2 \mathrm{~m}$ spacing $+100 \% \mathrm{~N}, 2 \mathrm{~m}$ spacing $+115 \% \mathrm{~N}, 2 \mathrm{~m}$ spacing $+130 \% \mathrm{~N}, 4 \mathrm{~m}+100 \% \mathrm{~N}, 4 \mathrm{~m}$ spacing + $115 \% \mathrm{~N}, 4 \mathrm{~m}$ spacing $+130 \% \mathrm{~N}$, respectively than control. The corresponding values of ESP are 13.56, 13.90, 13.22, $4.56,12.25$ and $11.85 \%$ after the first season and 18.81, 18.75, 19.38, 10.57, 15.74 and $16.93 \%$ after the second season respectively. Results could be attributed mainly to that subsoil forms many lines with big crack extent from soil surface to subsoil depth (60 $\mathrm{cm}$ deep) and also numerous effective capillary cracks is formed. All these cracks together break the soil matrix and encourage downward of water as well as solute movement. The soil cracks life may be several months or years (Moukhtar et al., 2002).Moukhtar et al, (2003) reported that, moling or subsoiling enhance downward movement of irrigation water carrying off excess salts from surface layers. After wards, regular subsequent irrigations will gradually reduce the salt content in groundwater at least when it is close to soil surface. Similar results were obtained byAiad et al., (2012) and Antar, et al., (2014) while, no obvious different for soil salinity and sodcity values under $\mathrm{N}$-fertilizerrates treatments in both seasons. 
Table 2:- Salinity and sodcity of the soil as affected by the different studied treatments.

\begin{tabular}{|c|c|c|c|c|c|}
\hline \multirow[t]{2}{*}{ Treatments } & \multirow{2}{*}{$\begin{array}{l}\text { Soil depth } \\
(\mathrm{cm})\end{array}$} & \multicolumn{2}{|c|}{ First season } & \multicolumn{2}{|c|}{ Second season } \\
\hline & & $\mathrm{EC} \mathrm{dSm}^{-1}$ & ESP & $\mathrm{EC} \mathrm{dSm}^{-1}$ & ESP \\
\hline \multirow{4}{*}{$\begin{array}{l}\text { Open drainage }+100 \% \mathrm{~N} \\
\text { (control) }\end{array}$} & $0-15$ & 7.86 & 16.04 & 7.78 & 16.51 \\
\hline & $15-30$ & 8.29 & 17.44 & 8.23 & 17.22 \\
\hline & $30-60$ & 10.43 & 19.16 & 10.48 & 19.07 \\
\hline & $60-90$ & 11.66 & 20.28 & 11.76 & 20.04 \\
\hline \multicolumn{2}{|c|}{ Average (0-60) } & 8.86 & 17.55 & 8.83 & 17.60 \\
\hline \multirow{4}{*}{$\begin{array}{l}\text { Mole drains at } 2 \mathrm{~m} \text { spacing } \\
+100 \% \mathrm{~N}\end{array}$} & $0-15$ & 6.44 & 14.22 & 5.34 & 13.05 \\
\hline & $15-30$ & 6.91 & 15.09 & 5.87 & 14.88 \\
\hline & $30-60$ & 7.63 & 16.21 & 7.01 & 14.95 \\
\hline & $60-90$ & 11.62 & 19.52 & 11.63 & 19.61 \\
\hline \multicolumn{2}{|c|}{ Average (0-60) } & 6.99 & 15.17 & 6.07 & 14.29 \\
\hline \multirow{4}{*}{$\begin{array}{l}\text { Mole drains at } 2 \mathrm{~m} \text { spacing } \\
+115 \% \mathrm{~N}\end{array}$} & $0-15$ & 6.53 & 14.33 & 5.53 & 13.27 \\
\hline & $15-30$ & 6.66 & 14.67 & 5.70 & 14.65 \\
\hline & $30-60$ & 7.69 & 16.34 & 6.96 & 14.98 \\
\hline & $60-90$ & 11.16 & 19.66 & 11.68 & 20.02 \\
\hline \multicolumn{2}{|c|}{ Average (0-60) } & 6.96 & 15.11 & 6.06 & 14.30 \\
\hline \multirow{4}{*}{$\begin{array}{l}\text { Mole drains at } 2 \mathrm{~m} \text { spacing } \\
+\quad 130 \% \mathrm{~N}\end{array}$} & $0-15$ & 6.78 & 14.16 & 5.13 & 13.45 \\
\hline & $15-30$ & 7.27 & 14.66 & 5.32 & 13.87 \\
\hline & $30-60$ & 8.01 & 16.87 & 6.88 & 15.24 \\
\hline & $60-90$ & 11.87 & 20.09 & 11.72 & 19.87 \\
\hline \multicolumn{2}{|c|}{ Average (0-60) } & 7.35 & 15.23 & 5.78 & 14.19 \\
\hline \multirow{4}{*}{$\begin{array}{l}\text { Mole drains at } 4 \mathrm{~m} \text { spacing } \\
+100 \% \mathrm{~N} .\end{array}$} & $0-15$ & 6.89 & 14.87 & 6.56 & 14.46 \\
\hline & $15-30$ & 7.54 & 15.93 & 7.43 & 15.48 \\
\hline & $30-60$ & 9.02 & 17.56 & 9.24 & 17.29 \\
\hline & $60-90$ & 11.27 & 20.62 & 11.35 & 19.86 \\
\hline \multicolumn{2}{|c|}{ Average (0-60) } & 7.82 & 16.75 & 7.74 & 15.74 \\
\hline \multirow{4}{*}{$\begin{array}{l}\text { Mole drains at } 4 \mathrm{~m} \text { spacing } \\
+115 \% \mathrm{~N}\end{array}$} & $0-15$ & 6.77 & 14.76 & 6.14 & 14.02 \\
\hline & $15-30$ & 7.65 & 15.27 & 7.05 & 14.35 \\
\hline & $30-60$ & 9.18 & 16.17 & 8.67 & 16.11 \\
\hline & $60-90$ & 11.34 & 20.47 & 11.24 & 20.44 \\
\hline \multicolumn{2}{|c|}{ Average (0-60) } & 7.87 & 15.40 & 7.29 & 14.83 \\
\hline \multirow{4}{*}{$\begin{array}{l}\text { Mole drains at } 4 \mathrm{~m} \text { spacing } \\
+130 \% \mathrm{~N}\end{array}$} & $0-15$ & 7.01 & 14.64 & 6.22 & 13.85 \\
\hline & $15-30$ & 7.44 & 15.74 & 6.44 & 14.67 \\
\hline & $30-60$ & 9.22 & 16.04 & 8.53 & 15.34 \\
\hline & $60-90$ & 11.24 & 20.41 & 11.30 & 20.04 \\
\hline \multicolumn{2}{|c|}{ Average $(0-60)$} & 7.89 & 15.47 & 7.06 & 14.62 \\
\hline
\end{tabular}

\section{Ratio of $\mathrm{Ca}^{++} / \mathrm{TSS}:-$}

Results in Table (3) show that, application of mole drains and added of gypsum seemed to be more effective on increasing $\mathrm{Ca}^{++} / \mathrm{TSS}$ ratio in the topsoil up to $60 \mathrm{~cm}$, than before application and control treatment. The increases of $\mathrm{Ca}^{++} /$TSS ratio after the second season are more pronounced compared to that after the first season. This may be due to the leachability of $\mathrm{Na}^{+}$is higher than that of $\mathrm{Ca}^{++}$and $\mathrm{Mg}^{++}$with mole drains. Also, $\mathrm{Na}^{+}$and $\mathrm{Cl}^{-}$are leached more readily than $\mathrm{SO}_{4}^{+}, \mathrm{Ca}^{++}$and $\mathrm{Mg}^{++}$. In this concern, Ali and Kahlown (2001) mentioned that reclamation of saline sodic and sodic soils, however, can not be achieved by simple leaching. Reclamation of these soils is difficult, time consuming and more expensive than that of saline soils due to replacement of exchangeable sodium with calcium.

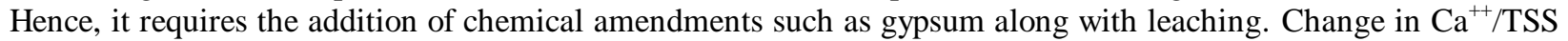
ratio were no observed in deeper layer $(60-90 \mathrm{~cm})$. Whereas, mole drains is effective in removing salts especially $\mathrm{Na}^{+}$from the topsoil up to $60 \mathrm{~cm}$. Results also, show that, narrow mole spacing $(2 \mathrm{~m})$ is superior to wider mole spacing $(4 \mathrm{~m})$ in increasing $\mathrm{Ca}^{++} / \mathrm{TSS}$ ratio. This may be due to the good effectiveness of narrow mole spacing (2m) than wider mole spacing $(4 \mathrm{~m})$. While, no obvious different betweenCa ${ }^{++} / \mathrm{TSS}$ ratio values under $\mathrm{N}$-fertilizerrates treatments in both seasons. 
Table 3:- $\mathrm{Ca}^{++} / \mathrm{TSSratio}$ of the soil as affected by the different studied treatments.

\begin{tabular}{|c|c|c|c|c|c|c|}
\hline \multirow[t]{2}{*}{ Treatments } & \multirow[t]{2}{*}{ Season } & \multicolumn{4}{|c|}{ Soil depth $(\mathrm{cm})$} & \multirow{2}{*}{$\begin{array}{l}\text { Average } \\
(0-60)\end{array}$} \\
\hline & & $0-15$ & $15-30$ & $30-60$ & $60-90$ & \\
\hline \multirow{2}{*}{$\begin{array}{l}\text { Open drainage }+100 \% \mathrm{~N} \\
\text { (control). }\end{array}$} & First & 17.24 & 15.65 & 13.51 & 13.02 & 15.47 \\
\hline & Second & 16.87 & 15.84 & 13.52 & 13.24 & 15.41 \\
\hline \multirow{2}{*}{$\begin{array}{l}\text { Mole drains at } 2 \mathrm{~m} \text { spacing }+ \\
100 \% \mathrm{~N} \text {. }\end{array}$} & First & 24.44 & 24.63 & 19.41 & 14.87 & 22.83 \\
\hline & Second & 25.89 & 24.87 & 20.12 & 14.32 & 23.63 \\
\hline \multirow{2}{*}{$\begin{array}{l}\text { Mole drains at } 2 \mathrm{~m} \text { spacing }+ \\
115 \% \mathrm{~N} \text {. }\end{array}$} & First & 24.31 & 24.56 & 18.24 & 13.41 & 22.37 \\
\hline & Second & 25.87 & 24.54 & 20.12 & 14.87 & 23.51 \\
\hline \multirow{2}{*}{$\begin{array}{l}\text { Mole drains at } 2 \mathrm{~m} \text { spacing }+ \\
130 \% \mathrm{~N} \text {. }\end{array}$} & First & 24.32 & 24.17 & 19.89 & 13.75 & 22.79 \\
\hline & Second & 26.42 & 24.35 & 20.2 & 14.32 & 23.66 \\
\hline \multirow{2}{*}{$\begin{array}{l}\text { Mole drains at } 4 \mathrm{~m} \text { spacing }+ \\
100 \% \mathrm{~N} \text {. }\end{array}$} & First & 23.45 & 23.45 & 18.74 & 14.74 & 21.88 \\
\hline & Second & 24.33 & 24.25 & 20.1 & 13.74 & 22.89 \\
\hline \multirow{2}{*}{$\begin{array}{l}\text { Mole drains at } 4 \mathrm{~m} \text { spacing }+ \\
115 \% \mathrm{~N} \text {. }\end{array}$} & First & 24.12 & 22.84 & 19.14 & 13.41 & 22.03 \\
\hline & Second & 25.13 & 23.42 & 19.54 & 14.12 & 22.70 \\
\hline \multirow{2}{*}{$\begin{array}{l}\text { Mole drains at } 4 \mathrm{~m} \text { spacing }+ \\
130 \% \mathrm{~N} \text {. }\end{array}$} & First & 23.45 & 23.54 & 18.86 & 14.11 & 21.95 \\
\hline & Second & 24.12 & 24.18 & 20.12 & 13.98 & 22.81 \\
\hline
\end{tabular}

Soil bulk density and Soil porosity:-

Soil bulk density is considered as one of the parameters which indicate the status of soil structure and consequently, soil water, air and heat regimes (Richards, 1954). Results in Table (4) show that, soil bulk density was increased with increasing soil depth for all tested profiles. This increase may be resulted from increasing soil compaction due to layers weight. Mole drainsapplication were reduced soil bulk density, especially in the topsoil up to $60 \mathrm{~cm}$. Soil bulk density before treatments application and control varied 1.35 to $1.41 \mathrm{Mgm}^{-3}$ and from 1.14 to $1.36 \mathrm{Mgm}^{-3}$ after two seasons from treatments application. It could be attributed to the effects of mole on breaking soil cods and bigger granular into smaller crumbs as well as breaking and cracking the compacted layers (Amer, 1999 and Abdel-Mawgoud et al., 2006). Results show that, narrow mole spacing $(2 \mathrm{~m})$ is superior to wider mole spacing $(4 \mathrm{~m})$ in reducing soil bulk density. This may be due to the good effectiveness of narrow mole spacing than wider mole spacing. While, no obvious different between soil bulk densityvalues under $\mathrm{N}$-fertilizerrates treatments. The average values of soil bulk density $(0-60 \mathrm{~cm})$ were $1.23,1.26$ and $1.25 \mathrm{Mgm}^{-3}$ for mole spacing of $2 \mathrm{~m}+100 \% \mathrm{~N}, 2 \mathrm{~m}$ spacing $+115 \%$ Nand $2 \mathrm{~m}$ spacing $+130 \% \mathrm{~N}$, respectively and were $1.28,1.29$ and $1.29 \mathrm{Mgm}^{-3}$ for mole spacing of $4 \mathrm{~m}+100 \% \mathrm{~N}, 4 \mathrm{~m}$ spacing $+115 \%$ Nand $4 \mathrm{~m}$ spacing $+130 \% \mathrm{~N}$, respectively.

Soil porosity values (Table 4) take almost the opposite trend to that encountered with bulk density. The results indicate that the values of bulk density were increased and values of total porosity were decreased with the depth for all treatments (Table 4). Jodi DeJong (2004) andAntar, et al., (2012) stated that the theory behind mole drain and subsoiling are to shatter a deep compacted layer in the soil to increase water movement, increase total porosity, create better aeration for the root and increase the availability of nutrients for plant growth.

\section{Infiltration rate (IR):-}

Basic infiltration rates (BIR) of soil as affected by different treatments are presented in Table (4).Datashow that, Mole drainsapplication were increased basic infiltration rate than before treatments application. Basic infiltration rates before treatments application was $0.61 \mathrm{~cm} / \mathrm{hr}$ while, after two seasons from treatments application varied from 1.56 to $1.85 \mathrm{~cm} / \mathrm{hr}$. This may be due to the subsurface tillage gave the top soil layer a chance to dry and permitted for shrinkage and formation of water passage ways which allowed a rather easier movement of water into subsoil line. Similar results were obtained by Abdel-Mawgoud et al., (2003 and 2006) and Antar et al., (2012).Results (Table 4)show that, narrow mole spacing $(2 \mathrm{~m})$ is superior to wider mole spacing $(4 \mathrm{~m})$ in increasing basic infiltration rate. This may be due to the good effectiveness of narrow mole spacing than wider mole spacing. The average values of basic infiltration rate were $1.84,1.79$ and $1.85 \mathrm{~cm} / \mathrm{hr}$ for mole spacing of $2 \mathrm{~m}+100 \% \mathrm{~N}, 2 \mathrm{~m}$ spacing $+115 \%$ Nand $2 \mathrm{~m}$ spacing $+130 \% \mathrm{~N}$, respectively and were $1.57,1.56$ and $1.61 \mathrm{~cm} / \mathrm{hr}$ for mole spacing of $4 \mathrm{~m}+100 \% \mathrm{~N}$, 4m spacing $+115 \%$ Nand $4 \mathrm{~m}$ spacing $+130 \% \mathrm{~N}$, respectively. While, no obvious different betweenbasic infiltration rate values under $\mathrm{N}$-fertilizerrates treatments. 
Table 4:-Bulk density, total porosity, penetration resistance (SPR) and Basic Infiltration rate (BIR) of the soil as affected by the different studied treatments (after two seasons).

\begin{tabular}{|c|c|c|c|c|c|}
\hline Treatments & $\begin{array}{l}\text { Soil depth } \\
\quad(\mathrm{cm})\end{array}$ & $\begin{array}{c}\text { Soil bulk } \\
\text { density } \\
\left(\mathrm{Mgm}^{-3}\right)\end{array}$ & $\begin{array}{c}\text { Soil } \\
\text { porosity }(\%)\end{array}$ & $\begin{array}{c}\text { Basic } \\
\text { infiltration } \\
\text { rate } \mathrm{cm} / \mathrm{hr} \text { ) }\end{array}$ & $\begin{array}{c}\text { Soil } \\
\text { penetration } \\
\text { resistance } \\
(\mathrm{MPa}) \\
\end{array}$ \\
\hline \multirow[t]{3}{*}{ Open drainage $+100 \% \mathrm{~N}$ (control). } & 0-15 & $\mathbf{1 . 3 5}$ & 49.06 & \multirow[t]{3}{*}{0.61} & 1.29 \\
\hline & 15-30 & 1.35 & 49.06 & & 1.31 \\
\hline & $30-60$ & 1.41 & 46.79 & & 1.39 \\
\hline \multicolumn{2}{|l|}{ Average (0-60) } & 1.37 & 48.30 & & $\mathbf{1 . 3 3}$ \\
\hline \multirow[t]{3}{*}{ Mole drains at $2 \mathrm{~m}$ spacing $+100 \% \mathrm{~N}$. } & 0-15 & 1.14 & 56.98 & \multirow[t]{3}{*}{1.84} & 0.95 \\
\hline & 15-30 & 1.25 & 52.83 & & 1.18 \\
\hline & $30-60$ & 1.31 & $\mathbf{5 0 . 5 7}$ & & 1.18 \\
\hline \multicolumn{2}{|l|}{ Average (0-60) } & $\mathbf{1 . 2 3}$ & 53.46 & & 1.10 \\
\hline \multirow[t]{3}{*}{ Mole drains at $2 \mathrm{~m}$ spacing $+115 \% \mathrm{~N}$. } & 0-15 & $\mathbf{1 . 1 8}$ & 55.47 & \multirow[t]{3}{*}{1.79} & 0.94 \\
\hline & 15-30 & 1.27 & 52.08 & & 1.12 \\
\hline & $30-60$ & 1.32 & 50.19 & & 1.09 \\
\hline \multicolumn{2}{|l|}{ Average (0-60) } & 1.26 & 52.58 & & 1.05 \\
\hline \multirow[t]{3}{*}{ Mole drains at $2 \mathrm{~m}$ spacing $+130 \% \mathrm{~N}$. } & $0-15$ & 1.18 & 55.47 & \multirow[t]{3}{*}{1.85} & 1.00 \\
\hline & 15-30 & 1.25 & 52.83 & & 1.00 \\
\hline & $30-60$ & 1.31 & 50.57 & & 1.18 \\
\hline \multicolumn{2}{|l|}{ Average $(0-60)$} & 1.25 & 52.96 & & 1.06 \\
\hline \multirow[t]{3}{*}{ Mole drains at $4 \mathrm{~m}$ spacing $+100 \% \mathrm{~N}$. } & 0-15 & $\mathbf{1 . 2 3}$ & 53.58 & \multirow[t]{3}{*}{1.57} & 1.11 \\
\hline & 15-30 & 1.28 & 51.70 & & 1.12 \\
\hline & $30-60$ & 1.33 & 49.81 & & 1.17 \\
\hline \multicolumn{2}{|l|}{ Average $(0-60)$} & 1.28 & 51.70 & & 1.13 \\
\hline \multirow[t]{3}{*}{ Mole drains at $4 \mathrm{~m}$ spacing $+115 \% \mathrm{~N}$. } & 0-15 & 1.24 & 53.21 & \multirow{3}{*}{1.56} & 1.07 \\
\hline & 15-30 & 1.28 & 51.70 & & 1.12 \\
\hline & $30-60$ & 1.34 & 49.43 & & 1.18 \\
\hline \multicolumn{2}{|l|}{ Average (0-60) } & 1.29 & 51.45 & & 1.12 \\
\hline \multirow[t]{3}{*}{ Mole drains at $4 \mathrm{~m}$ spacing $+130 \% \mathrm{~N}$. } & 0-15 & 1.24 & 53.21 & \multirow[t]{3}{*}{1.61} & 1.01 \\
\hline & 15-30 & 1.27 & 52.08 & & 1.12 \\
\hline & $30-60$ & 1.36 & 48.68 & & 1.12 \\
\hline Average (0-60) & & 1.29 & 51.32 & & 1.08 \\
\hline
\end{tabular}

\section{Soil penetration resistance:-}

Soil penetration resistance (SPR) as affected by different treatments for the studied soil profile $(0-60 \mathrm{~cm}$ depth) is presented in Table (4). Data show that, the high values of SPR (varied from 1.29 to 1.39 MPa) were found with control treatment, and the low values (varied from 0.94 to $1.18 \mathrm{MPa}$ ) were found after two seasons from treatments application.This means that mole drains effect was more superiority on reducing soil penetration resistance. It could be attributed to the effects of moiling on breaking soil clods and bigger granular into smaller crumbs as well as breaking and cracking the compacted layers (Amer, 1999, Abdel-Mawgoud et al., 2006 andAiad et al., (2012). Also, narrow mole spacing $(2 \mathrm{~m})$ is superior to wider mole spacing $(4 \mathrm{~m})$ in reducing soil penetration resistance. This may be due to the good effectiveness narrow mole spacing than wider mole spacing. Results show that, no obvious trend with soil penetration resistance values under $\mathrm{N}$-fertilizerrates treatments.

\section{Yield:-}

Data in Table (5) indicate clearly thatmole drains application caused significant increases for root, top and sugar yields compared to control. The yields were increased when the EC decreases as affected by mole drains and gypsum application. It can be concluded that heavy clay salt affected soils could have good productivity with the execution of mole drains and gypsum. While, there were insignificant differences within treatments after application. Data in Table (5) show that, there were no obvious differences between top yield in the first seasons only (ton fed ${ }^{-1}$ ) while significant differences were found between values of percentages of sucrose \% with all treatments. Significant differences were observed between mean values of root yields. The overall average ofroot yields were higher after application of mole drains than control by 4.95, 6.45, 7.05, 5.18, 6.75 and 7.07 tonfed. $^{-1}$ for $2 \mathrm{~m}-\mathrm{mole}$ spacing + 
$100 \% \mathrm{~N}, 2 \mathrm{~m}$-mole spacing $+115 \% \mathrm{~N}, 2 \mathrm{~m}$-mole spacing $+130 \% \mathrm{~N}, 4 \mathrm{~m}$-mole spacing $+100 \% \mathrm{~N}, 4 \mathrm{~m}$ spacing + $115 \%$ Nand $4 \mathrm{~m}$ spacing $+130 \% \mathrm{~N}$, respectively. The corresponding values of gross sugar yield were $0.81,1.06$, $1.17,0.88,1.10$ and 1.17 tonfed. $^{-1}$, respectively. Such findings may be attributed to the effect of mole drains and gypsum on improving soil properties which effects on water-air relationships in the root zone and increase the root penetration. In this regard, Abdel-Mawgoud et al., (2006) mentioned that the subsurface tillage was superior in enhancing the root yield. It can be concluded that under such conditions the mole drains and gypsum are the most effective treatments that ameliorate saline sodic clay soil. Similar results were obtained by Lickacz (1993), Aiad et al., (2012) and El-Sanat et al., (2012). sugar beet yields are increased with increasing N-fertilizer rate (from 100 to 115 and $130 \%$ from the recommended N) with both mole spacing in both seasons. Similar results were obtained by Korany and El-Said (1998), El-Shahawy et al. (2001). And Hamad et al (2015) they reported that root and top yields increased with increasing N rates up to $90 \mathrm{~kg} \mathrm{~N} / \mathrm{fed}$. Average of Juice purity $\%$ with open drainage $+100 \%$ $\mathrm{N}$ (control) was $77.36 \%$ while, after treatments application varied from 79.23 to $81.48 \%$.

Quality of juice significantly affected by nitrogen levels, addition $100 \% \mathrm{~N}$ as control gave the highest root quality in both seasons $(81.48$ and $81.22 \%$ ) respectively. This trait related to alkaline coefficient which gave maximum and optimum values compared with other nitrogen levels which gave lowest ones.

Table 5:- Sugar beet characters with different studied treatments.

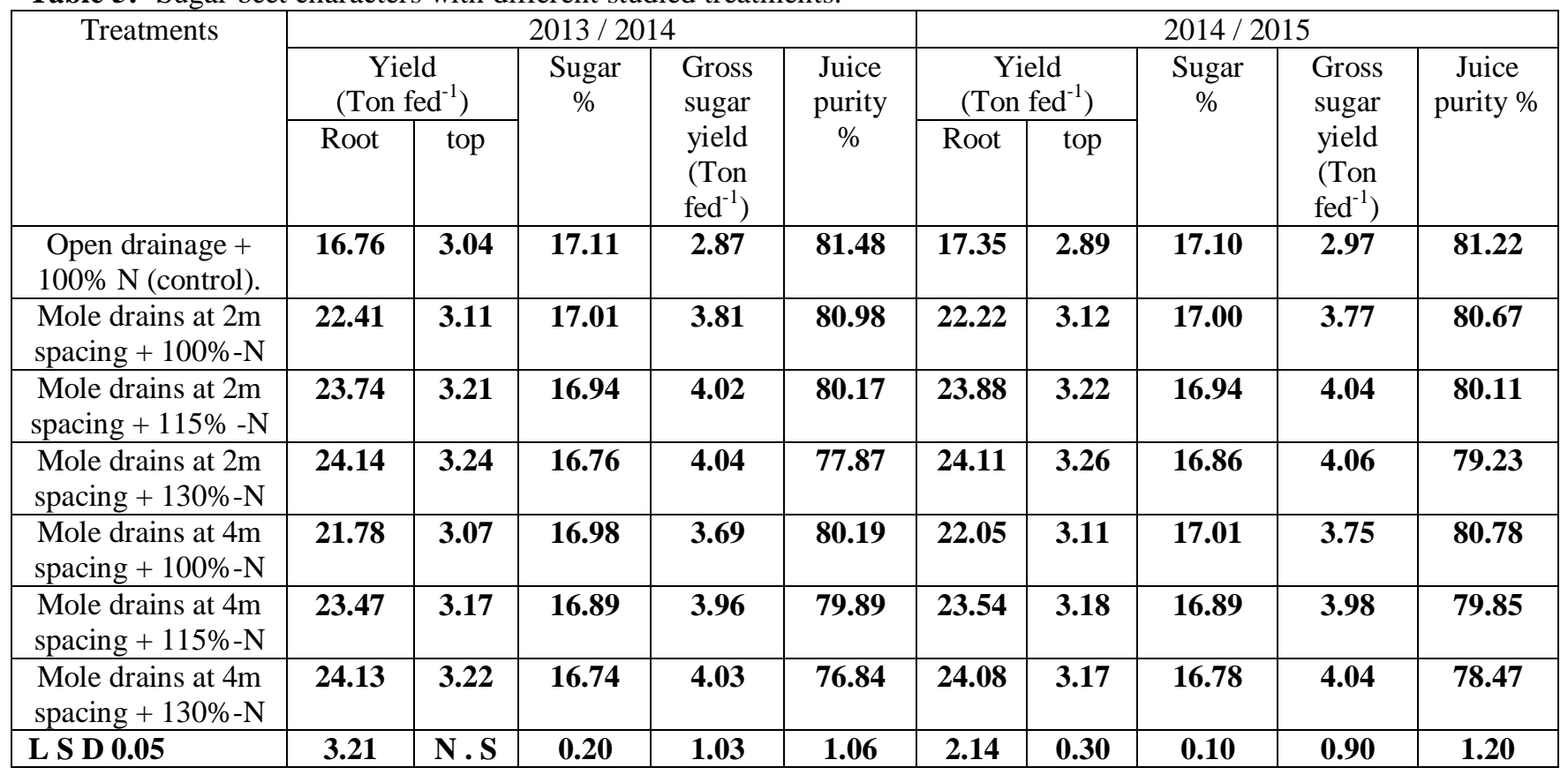

Data in Table (6) showed clearly that the N-uptake (kg/fed.) by roots and tops of sugar beetwere parallel to the yield results in both seasons. Whereas, mole drains application and increasing N-fertilizer rate (from 100 to 115 and $130 \%$ from the recommended $\mathrm{N}$ ) caused increases for $\mathrm{N}$-uptake by sugar beet roots and topscompared to control. The low values of $\mathrm{N}$-uptake ( 35.20 and $\left.36.44 \mathrm{kgfed}^{-1}\right)$ were found with control treatment, while the high ones (44.10 and 55.38 $\mathrm{kgfed}^{-1}$ ) were found after treatments application in both seasons, respectively.The high values of impurities (K and Na) in sugar beet roots were found with control treatment, while the low ones were found after treatments application in both seasons. On the other side $\alpha$-amino- $\mathrm{N}$ take opposite trend than $\mathrm{K}$ and $\mathrm{Na}$ in both seasons and gave lowest values with control. 
Table 6:-N-uptake of Sugar beet $\left(\mathrm{kg} \mathrm{fed}^{-1}\right), \mathrm{K}, \mathrm{Na}$ and $\alpha$-amino-N with different studied treatments.

\begin{tabular}{|c|c|c|c|c|c|c|c|c|c|c|c|c|}
\hline \multirow[t]{3}{*}{ Treatments } & \multicolumn{6}{|c|}{$2013 / 2014$} & \multicolumn{6}{|c|}{$2014 / 2015$} \\
\hline & \multicolumn{2}{|c|}{$\begin{array}{l}\text { N-uptake } \\
\left(\mathrm{kg} \mathrm{fed}^{-1}\right)\end{array}$} & \multirow[t]{2}{*}{ K } & \multirow[t]{2}{*}{$\mathrm{Na}$} & \multirow{2}{*}{$\begin{array}{c}\alpha- \\
\text { amin } \\
\mathrm{o} \\
\mathrm{N}\end{array}$} & \multirow[t]{2}{*}{ A C } & \multicolumn{2}{|c|}{$\begin{array}{l}\text { N-uptake } \\
\left(\mathrm{kg} \mathrm{fed}^{-1}\right)\end{array}$} & \multirow[t]{2}{*}{ K } & \multirow[t]{2}{*}{$\mathrm{Na}$} & \multirow{2}{*}{$\begin{array}{c}\alpha- \\
\text { amino } \\
N\end{array}$} & \multirow[t]{2}{*}{ A C } \\
\hline & Root & TOP & & & & & Root & TOP & & & & \\
\hline $\begin{array}{c}\text { Open drainage + } \\
100 \% \mathrm{~N} \text { (control). }\end{array}$ & 35.20 & 21.32 & 7.85 & 2.74 & 2.80 & 3.78 & 36.44 & 23.21 & 8.21 & 2.77 & 2.84 & 3.87 \\
\hline $\begin{array}{l}\text { Mole drains at } 2 \mathrm{~m} \\
\text { spacing }+100 \%-\mathrm{N}\end{array}$ & 50.09 & 21.54 & 5.47 & 1.88 & 3.41 & 2.16 & 50.66 & 22.45 & 6.41 & 1.78 & 3.42 & 2.39 \\
\hline $\begin{array}{l}\text { Mole drains at } 4 \mathrm{~m} \\
\text { spacing }+115 \%-\mathrm{N}\end{array}$ & 53.98 & 23.54 & 5.99 & 1.87 & 3.67 & 2.14 & 54.14 & 24.73 & 6.01 & 1.88 & 3.67 & 2.15 \\
\hline $\begin{array}{l}\text { Mole drains at } 2 \mathrm{~m} \\
\text { spacing }+130 \%-\mathrm{N}\end{array}$ & 54.78 & 19.25 & 6.24 & 1.69 & 4.55 & 1.74 & 55.38 & 20.24 & 6.42 & 1.97 & 4.85 & 1.73 \\
\hline $\begin{array}{l}\text { Mole drains at } 4 \mathrm{~m} \\
\text { spacing }+100 \%-\mathrm{N}\end{array}$ & 44.82 & 21.25 & 6.86 & 2.01 & 3.21 & 2.76 & 44.10 & 20.58 & 6.67 & 1.99 & 3.11 & 2.78 \\
\hline $\begin{array}{l}\text { Mole drains at } 4 \mathrm{~m} \\
\text { spacing }+115 \%-\mathrm{N}\end{array}$ & 53.18 & 22.31 & 6.74 & 1.89 & 3.58 & 2.41 & 54.45 & 24.25 & 6.73 & 2.14 & 3.87 & 2.29 \\
\hline $\begin{array}{l}\text { Mole drains at } 4 \mathrm{~m} \\
\text { spacing }+130 \%-\mathrm{N}\end{array}$ & 54.56 & 20.25 & 6.45 & 2.13 & 3.96 & 2.47 & 54.49 & 21.25 & 6.72 & 2.21 & 3.89 & 2.30 \\
\hline L S D 0.05 & 13.10 & 1.02 & 0.90 & 0.81 & 0.75 & 0.65 & 10.14 & 1.95 & 0.77 & 0.35 & 0.55 & 0.84 \\
\hline
\end{tabular}

Potassium, sodium and alfaamino nitrogen $(\mathrm{K}, \mathrm{Na}$ and $\alpha-\mathrm{N})$ were determined as ( $\mathrm{g} / 100 \mathrm{~g}$ sugar)Alkaline coefficient:-

Regarding to alkaline coefficient as affected by mole drains and nitrogen levels, data presentedin Table (6) cleared that with increasing nitrogen levels up to $100 \%$ from recomendation dose to $130 \%$ caused to decreasing (AC) to $(1.74$ and 1.73) in both seasons, This mean that if (Ac) decrease than (1.8) this indicator that over fertilization happen. So, we must take care from increasing nitrogen dose which decreasing (Ac) low than (1.8).

\section{Conclusion:-}

* Molingis good way in clay soils to reserve the root zone from water logging and salinity in presence gypsum.

* Mole draintend to improve soil physio-chemical characteristics and increase sugar beet production.

\section{References:-}

1. Abdel-Mawgoud A.S.A, , M. B. El Shewikh, A. N. Abdel-Aal and M.I.I. Abdel-Khalik (2003).Open drainage and moiling for desalinization of Salty Clay Soils of Northeastern Egypt. Presented at the 9th International Drainage Workshop, September 10 - 13, 2003, Utrecht, The Netherlands.

2. Abdel-Mawgoud A.S.A, A.A.S. Gendy and S.A. Ramadan (2006). Improving root zone environment and production of a salty clay soil using subsoiling and gypsum application. Assiut J. of Agri. Sci., 37, 2: 147-164.

3. Ahmad, N., Qureshi, R.H. and M. Qadir, (1990). Amelioration of a calcareous saline-sodic soil by gypsum and forage plants. Land Degradation and Rehabilitation, 2, 277-284.

4. Aiad M.A.F., M.A. Abd El-Aziz, B.A.A. Zamil and A.S. Antar (2012). Combating of soil deterioration at north delta, Egypt. J. Agric. Res. Kafr El-Sheikh Univ., 38 (2), 322-341.

5. Ali, T. and M.A. Kahlown (2001). Role of gypsum in amelioration of saline-sodic and sodic soil. International Journal of Agriculture and Biology. 3(3): 326-332.

6. Amer, M. H. (1999). Effect of tillage operations on some soil physical properties and water relations of corn. Egypt, J. Appl. Sci., 14 (6):354-365.

7. AntarA. S.; G. M. A. El-Sanat and H. A. Khafagi (2014). Improving heavy clay salt affected soil and its production using some amendments application in north delta. J, of Soil Sciences and Agricultural Engineering. Mansoura Univ. Vol. 5 (12): 1717-1730

8. Antar, S. A.; A. S. El-Henawy and A. A. E. Atwa (2008). Improving some properties of heavy clay salt affected soil as a result of different subsurface tillage. J. Agric. Sci. Mansoura Univ., 33 (10): 7675- 7687.

9. Antar, S. A.; Mohamedin, A.A.M. and El-Meligy, A.M. (2012).Improving root zone and production of clay salt affected soil as a result of different subsurface tillage. $11^{\text {th }}$ ICID International Drainage Workshop on Agricultural Drainage Needs and Future Priorities. Cairo, Egypt September 23 - 27 
10. Campbell, D.J. (1994). Determination and use of bulk density in relation to soil compaction. In Soane and Ouwerk (Eds). Soil compaction in crop production. Elsever, London and Amsterdam.

11. David Hopkins, Colac (2002). Managing wet soils: mole drainage. WWW.dse. Vic. Gov.

12. Duncan, D.B. (1955). Multiple range and multiple F-test Biometrics, 11: 1.

13. El-Sanat G. M. A., M.A. Aiad, A. S. Antar, and B.A. Zamil (2012). Effect of tillage methods and depths on sugar beet and rice yields, salt distribution and water use efficiency in salt affected soils at North Delta.Minufiya J. Agric. Res. Vol. 37, No. 5(2):1307-1323.

14. El-Shahawy, M.I.; M.S. El-Yamani; MaaniZ.M.Abou-Amou and Asmaa A. El-Basuony (2001). Influence of tillage methods and nitrogen fertilization levels on yield, quality and chemical composition of sugar beet crop. J Agric. Sci. Mansoura Univ., 26(2):1177-1190.

15. Garcia, G. (1978). Soil water Engineering Laboratory Manual. Colorado State Univ. Dept. of Agric. and Chemical Engineering. Fortcollins, Colorado.

16. Hamad, A . M. ,H . M. Sarhan and S.S.Zalat .(2015) . Effect of nitrogen , Potassium fertilizer and plant distribution patterns on yield and quality of sugar Beet . J . Agric . Res . Mansoura univ ., vol . 6 (4) : 617 - 627

17. Jodi DeJong, H. (2004). Can subsoiling increase crop yields in Minnesota? Agric. World Wide Correspondent. Meredith Coporation.

18. Korany, M.S. and El-Said M. A. Khalifa (1998). Effect of tillage methods and nitrogen fertilizers on sugar beet production. Misr, J. Ag. Eng.15 (2)261-275.

19. Lickacz, J. (1993). Management of solonetzic soils. Agdex 518-8. Revised, Edmonton, Alberta, Canada.

20. Moukhtar, M. M., E. M. El-Hadidy, M.Y.S. El-Arquan And M.A.B. El-Shewikh (2002). Soil Amelioration Technique of Cover Drainage Combined Subsoiling for Saline-Sodic Clay in North Egypt. XVth World Congress of the International Commission of Agricultural Engineering (CIGR) on July 28-31 - 2002, Chicago, USA.

21. Moukhtar, M.M., M.Y.S. El-Arquan, E.M. El-Hadidy and M.A.B. El-Shewikh (2003). Amelioration of salt affected soils in north Dakhlia Governorate through application of tile drainage and subsoiling. J. Agric. Sci. Mansoura Univ., Special Issue, Sci. Symp. On Problems of soils and waters in Dakhlia and Damietta Governorate. March 18.

22. Oster, J.D., I. Shainberg and I.P. Abrol, (1996). Reclamation of salt affected soils. In: Soil erosion, conservation and rehabilitation (ed.M. Agassi), pp. 315-352. Marcel Dekker, New York.

23. Page, A.L.; R.H. Miller and D.R. Keeney (1982). Methods of Soil Analysis. Part П: Chemical and microbiological properties, $2^{\text {nd }}$ ed. Soil Sci. Soc. Am. Inc., Madison, USA.

24. Pessarakli, M., (2010). Handbook of plant and crop stress. Third Edition. CRc press.

25. Pollach ,G. (1984). Devolopment and utilization of quality criteria for sugar beet in ustralia . paper presented to the $27^{\text {th }}$ technological conference, British sugar Plc .22 pp.

26. Reda, M.M.A., (2006).Amelioration techniques for saline sodic soils in north Nile delta and its impact on sunflower productivity. Egypt. J. Appl. Sci. 21:213-228.

27. Rees R. M., M. Roelcke, X. O. Wang and J. Richter (1995). The effect of fertilizer placement on nitrogen uptake and yields of wheat and maize in chinese losses soil. Nutrient cycling in agroecosystems. 47 (1): $81-91$.

28. Richards, L.A. (1954). Diagnosis and Improvement of Saline and Alkali Soils U.S.D.A. Hand Book No. 60.

29. Sendecor, G.W. and W.G. Cochran (1980). "Statistical Methods" 7th ed., 225-330. Iowa state Univ., Press., Ames., Iowa, USA.

30. Wieninger,l. and N . Kubadino,(1971).BeziehungenzwischenRubenanalysen und technologichebewertung von zucherruben . in conptesrendus de la xiv ${ }^{\mathrm{me}}$ assemblee general de la commision international de sucrerie ,pp. 52338 . 